\title{
Analysis of the profile of brazilian fellowship researchers productivity in physiology:
}

\section{observational study}

\author{
Análise do perfil de produtividade de pesquisadores bolsistas brasileiros em fisiologia: estudo \\ observacional
}

Análisis del perfil de la productividad de los investigadores becarios brasileños en fisiología: estudio observacional

Received: 07/30/2021 | Reviewed: 08/03/2021 | Accept: 08/06/2021 | Published: 08/11/2021

\author{
Michelly Cardoso Silva \\ ORCID: https://orcid.org/0000-0002-6745-490X \\ Federal University of Sergipe, Brazil \\ E-mail: michelly1095@gmail.com \\ Josimari Melo DeSantana \\ ORCID: https://orcid.org/0000-0003-1432-0737 \\ Federal University of Sergipe, Brazil \\ E-mail: josimelo@academico.ufs.br
}

\begin{abstract}
In view of the devaluation of Brazilian education and science observed in recent years and considering the importance of Physiology as basic science it is necessary to carry out the general mapping of this area by analyzing the profile of productivity researchers fellows and, therefore, highlight possible discrepancies existing between the different levels of categories. This is an observational, descriptive study. Free access was made to the information contained on National Council for Scientific and Technological Development website for the identification of PQ fellows. We found 193 PQ fellowship in Physiology, 72\% of which were located in the Southeast region. We also observed a predominance of male fellowships (54.9\%). Regarding the distribution by public and private sectors, $94.8 \%$ were in the public service. Among the Institutions where the researchers were located, 6 of them are responsible for $52.4 \%$ of the PQ fellowships. When analyzing the total number of PG programs reposted in the Lattes, we found a total of 152 PG programs, of which 46 are in the area of CBII. We conclude that although researchers from all over the Brazilian territory may apply for a Productivity Grant, these are still concentrated in the Southeast region, thus revealing the disparity in distribution. We also highlight the distribution of fellowship by sex, indicating a predominance of males, especially at higher hierarchical levels. Based on our data, the most researchers are linked to only one graduate program and $27.6 \%$ of them are allocated to the area of Biological Science II.
\end{abstract}

Keywords: Scientific production; Research productivity; CNPq; Biological science disciplines; Physiology.

\section{Resumo}

Tendo em vista a desvalorização da educação e ciência brasileira observada nos últimos anos e considerando a importância da Fisiologia não só enquanto ciência básica faz-se necessário realização do mapeamento geral dessa área por meio da análise do perfil dos pesquisadores em produtividade (PQ) e, com isso, destacar possíveis discrepâncias existentes entre os diferentes níveis de categorias. Trata-se de um estudo observacional, descritivo. Fez-se acesso livre às informações contidas no site Conselho Nacional de Desenvolvimento Científico e Tecnológico (CNPq) para identificação dos bolsistas PQ. Encontramos 193 bolsistas PQ em Fisiologia, sendo que 72\% estavam localizados na região Sudeste. Observamos ainda predominância de bolsistas do sexo masculino (54.9). No que diz respeito a distribuição por setores Público e Privado, 94.8\% encontravam-se no setor Público. Dentre as Instituições em que os pesquisadores estavam locados, 6 delas são responsáveis por 52.4\% dos bolsistas PQ. Quando analisada a quantidade total de programas de PG relatados no Lattes, encontramos um total de 152 programas de PG, dos quais 46 estão inseridos na área CBII. Concluímos que, embora pesquisadores de todo território brasileiro possam pleitear Bolsa Produtividade, estas ainda se mantêm concentradas na região Sudeste, revelando, assim, a disparidade presente na distribuição. Destacamos, ainda, a distribuição das bolsas por sexo, apontando predomínio do sexo masculino, especialmente em níveis hierárquicos mais altos. Baseado em nossos dados, a maioria dos pesquisadores estão vinculados em apenas um programa de pós-graduação e 27.6\% deles estão alocados na área Ciências Biológicas II.

Palavras-chave: Produção científica; Produtividade em pesquisa; CNPq; Ciências biológicas; Fisiologia. 


\section{Resumen}

En vista de la devaluación de la educación y la ciencia brasileñas observada en los últimos años y considerando la importancia de la Fisiología no solo como ciencia básica, es necesario realizar un mapeo general de esta área a través del análisis del perfil de los investigadores de productividady, por lo tanto, resaltar las posibles discrepancias que existen entre los diferentes niveles de categorías. Este es un estudio observacional descriptivo. Se realizó acceso gratuito a la información contenida en el sitio web del CNPq para la identificación de los bencarios PQ. Encontramos 193 becas PQ en Fisiología, el 72\% de los cuales se ubicaron en la región Sudeste. También observamos un predominio de becarios varones (54,9). En cuanto a la distribución por sector público y privado, el 94,8\% correspondió al sector público. Entre las Instituciones donde se ubicaron los investigadores, 6 de ellos son responsables del 52,4\% de los becarios PQ. Al analizar la cantidad total de programas PG reportados en Lattes, encontramos un total de 152 programas PG, de los cuales 46 están insertados en el área CBII. Concluimos que, si bien los investigadores de todo el territorio brasileño pueden solicitar una Beca de Productividad, aún se concentran en la región Sudeste, lo que revela la disparidad presente en la distribución. También destacamos la distribución de las becas por género, lo que indica un predominio del sexo masculino, especialmente en los niveles jerárquicos superiores. Según nuestros datos, la mayoría de investigadores están vinculados a un solo programa de posgrado y el 27,6\% de ellos están asignados al área de Ciencias Biológicas II.
\end{abstract}

Palabras clave: Producción científica; Productividad de la investigación; CNPq; Ciencias biológicas; Fisiología.

\title{
1. Introduction
}

Brazilian scientific production, according to a report produced by Clarivate Analytics in 2018, ranked $13^{\text {th }}$ worldwide, a fact that reflects the growth of national productivity (Cross, Thomson, \& Sibclair, 2018). According to data from the Ministry of Science, Technology, Innovations and Communications, the number of publications indexed in Scopus jumped from 40.811 in 2008 to 74.195 in 2018 (Brasil, 2019). Such information corroborates the impacts of citations of Brazilian production, corresponding to an increase of $18 \%$ in recent years (Cross et al., 2018).

Nacional Council for Scientific and Technological Development (CNPq, as well known in Brazil), one of the main funding agencies for Brazilian scientific research, created the Research Productivity fellowship program. This type of fellowship is attributed to researchers according to not only the quantity, but mainly the quality of their production in their respective areas of expertise (Wainer \& Vieira, 2013). To this end, public notices are offered in which researchers holding the title of doctor and of outstanding production can competitively request the resource, based on criteria established by the advisory committees of their respective areas (Santos, Cândido, \& Kuppens, 2010; Sturmer, Viero, Silveira, Lukrafka, \& Plentz, 2013).

Productivity researchers (PQ, as called in Brazil) are classified and ranked in three broad categories: PQ-1 (involving the subcategories 1A, 1B, 1C and 1D), PQ-2 and Senior (PQ-SR), the latter being granted to researchers who remined in categories 1A or 1B for at least 15 years (Jean Paul Kamdem et al., 2019; Sacco et al., 2016). CNPq productivity grant is awarded to scientist according to the quality of this projects submitted in the public notices, training of human resources and relevant scientific contribution in their area of expertise (Jean Paul Kamdem et al., 2019).

Several studies aiming to verify the profile of PQ fellowships have been caried out over the past few years. We highlight analyzes for this propose in some areas such as Collective Health, Dentistry, Chemistry, Psychology, Medicine, Cardiology, Physiotherapy, Education, Pharmacology and Biomedical Science (Barata \& Goldbaum, 2003; Jean P. Kamdem et al., 2016; Jean Paul Kamdem et al., 2019; Leite \& Neto, 2017; Martelli-Junior et al., 2010; Oliveira et al., 2011; Sacco et al., 2016; Santos et al., 2010; Scarpelli, Sardenberg, Goursand, Paiva, \& Pordeus, 2008; Sturmer et al., 2013), revealing, therefore, the interest in investigating how the distribution of these fellowship has been in the different areas.

We are not aware of any study that has investigated the profile of PQ fellows in Physiology. However, we found a study that investigated the profile of fellows in Biological Science, thus include Biochemistry, Biophysics, Pharmacology and Physiology. However, data from only researchers included in the PQ-1 category were presented (1A, 1B, 1C and 1D) (Jean Paul Kamdem et al., 2019). 
In view of the devaluation of Brazilian education and science observed in recent years and considering the importance of Physiology not only as a basic science, but as an area of fundamental knowledge in the development of various professions, it is necessary to carry out the general mapping of this area and, with this, highlight possible discrepancies between different categories. Thus, we aim to analyze the profile of CNPq research productivity fellows in Physiology.

\section{Methods}

This is an observational, cross-sectional, descriptive study (Pereira, Shitsuka, Parreira, \& Shitsuka, 2018). Such research intends to observe, register and correlate facts without manipulating them (Leite \& Neto, 2017).

Initially, CNPq website (http://plsql1.cnpq.br/divulg/RESULTADO_PQ_102003.curso) was consulted in order to verify how many physiology productivity fellows were in an active situation. The information was obtained in May 2020.

Data for this research were obtained from CNPq, Lattes and Sucupira platforms, which are used throughout the country. Lattes platform aims to record the scientific productivity and academic career of these who use it, while Sucupira is characterized as a database containing information regarding analyzes and evaluations of Graduate Programs registered in the Brazilian Nacional Graduate System.

From the Lattes Curriculum of the researchers identified as PQ fellowship holders, made available by the Lattes platform $(\mathrm{CNPq})$, a database was built with information regarding the distribution of fellowship by category (1A, 1B, 1C, 1D and 2), geographic distribution, institutional and between the public and private sectors, doctorate time, training of human resources (master's, doctorate, post-doctorate and scientific initiation), scientific production (scientific articles and bibliometric indexes).

We also sought to find out which postgraduate programs these researchers were linked to, their respective areas of assessment with CAPES, how many of these programs were classified as participants in the category Biological Sciences II (an area that encompasses Physiology courses, in addition to Biophysics, Biochemistry, Pharmacology and Morphology) and their respective concepts of evaluation. This information was extracted from the Sucupira platform, the reference base of the National Graduate System provided by the Coordination for the Improvement of Higher Education Personnel (CAPES).

After building the database using an electronic spreadsheet (Excel-2016), analysis of data obtained was performed.

\section{Results}

Currently, CNPq offers 15.122 fellowships distributed in three areas: Engineering, Exact and Earth Science; Applied Human and Social Science; Life Sciences. Physiology is included in the broad area of Life Science. We identified 193 fellows in Physiology research productivity with current fellowship in May 2020, which corresponds to $1.27 \%$ of the total amount of fellowships distributes in the country, considering information provided by CNPq site. There was a predominance of male fellowship holders $(54.9 \%)$ in general. However, when analyzing the distribution by sex in different categories, we found a predominance of males in the highest categories $1 \mathrm{~A}, 1 \mathrm{~B}$ and $1 \mathrm{C}(7.3 \%, 10.4 \%$ and $7.2 \%$, respectively), and females in categories $1 \mathrm{D}$ and 2 (8.3\% and $27.5 \%$, respectively). Regarding the number of fellows by category, PQ-2 category stands out with 98 fellows (58.8\%). Details regarding the individual categories are shown in Table 1. 
Table 1: Distribution of CNPq productivity grants by sex and their respective percentages (\%).

\begin{tabular}{ccccccc}
\hline Fellowship modality & \multicolumn{2}{c}{ Male } & \multicolumn{2}{c}{ Female } & \multicolumn{2}{c}{ Total } \\
& $\mathrm{N}$ & $\%$ & $\mathrm{~N}$ & $\%$ & $\mathrm{~N}$ & $\%$ \\
\hline PQ-1A & 14 & 7.3 & 2 & 1 & 16 & 8.3 \\
\hline PQ-1B & 20 & 10.4 & 4 & 2.1 & 24 & 12.5 \\
\hline PQ-1C & 14 & 7.2 & 12 & 6.2 & 26 & 13.4 \\
\hline PQ-1D & 13 & 6.7 & 16 & 8.3 & 29 & 15 \\
\hline PQ-2 & 45 & 23.3 & 53 & 27.5 & 98 & 50.8 \\
\hline Total & 106 & 54.9 & 87 & 45.1 & 193 & 100 \\
\hline
\end{tabular}

CNPq: Nacional Council for Scientific and Technological Development; PQ: Productivity researchers; N: absolute frequency. Source: Authors own elaboration (2021).

Regarding the survey of fellows by demographic region, the Southeast region has $72 \%$ of fellows in Physiology, the remaining $28 \%$ are distributed in other regions of the country, $19 \%$ in the South, $6 \%$ in the Northeast, $2 \%$ in the Central-West and $1 \%$ in the North. We also highlight that $94.8 \%$ of fellowship holders work in the public service while $5.2 \%$ work in the private sector. We emphasize that all fellows allocated to the private sector were located in the Southeast (3.1\%) and South (2.1\%) regions.

The Southeast region has the largest number of fellows in all categories, followed by South region, with emphasis on the categories PQ-1C and PQ-2. The Northeast region presents fellowship holders only in the categories PQ-1B, PQ-1D and PQ-2. In the Central-West region, we found fellowship in the categories PQ-1C and PQ-2. The North region presents productivity grants only for the PQ-2 category. The percentage of each category by region are described in Table 2 .

Table 2: Distribution of CNPq productivity grants by region in numbers (n) and percentage (\%).

\begin{tabular}{ccccccccccc}
\hline Modality & \multicolumn{2}{c}{ Southeast } & \multicolumn{2}{c}{ South } & \multicolumn{2}{c}{ Northeast } & \multicolumn{2}{c}{ Central-West } & \multicolumn{2}{c}{ North } \\
& $\mathrm{N}$ & $\%$ & $\mathrm{~N}$ & $\%$ & $\mathrm{~N}$ & $\%$ & $\mathrm{~N}$ & $\%$ & $\mathrm{~N}$ & $\%$ \\
\hline PQ-1A & 14 & 87.5 & 2 & 12.5 & 0 & 0 & 0 & 0 & 0 & 0 \\
\hline PQ-1B & 19 & 79.2 & 3 & 12.5 & 2 & 8.3 & 0 & 0 & 0 & 0 \\
\hline PQ-1C & 19 & 73.1 & 6 & 23.1 & 0 & 0 & 1 & 3.8 & 0 & 0 \\
\hline PQ-1D & 21 & 72.4 & 5 & 17.2 & 3 & 10.4 & 0 & 0 & 0 & 0 \\
\hline PQ-2 & 65 & 66.3 & 21 & 21.4 & 7 & 7.2 & 3 & 3.1 & 2 & 2 \\
\hline
\end{tabular}

CNPq: Nacional Council for Scientific and Technological Development; PQ: Productivity researchers; N: Absolute frequency. Source: Authors own elaboration (2021).

When analyzing the bond institutions of the fellowship researchers, we found a total of 46 universities in the country where the researchers are distributed, and 6 of them are responsible for 52.4\% of the PQ fellowship holders: USP (19.7\%), UFRJ (7.8\%), UNIFESP (7.8\%), UFMG (6.7\%), UFRGS (5.2\%) and UNICAMP (5.2\%). The most of them are located in the Southeast, only one is located in the South. Other institutions as well as their respective locations, number of fellows and percentage that they represent in the general quantitative are available in Table 3. 
Table 3: Classification of institutions according to the number of PQ fellows in Physiology.

\begin{tabular}{|c|c|c|c|c|c|c|c|}
\hline Institutions & Position & $\begin{array}{c}\text { Ranking Folha } \\
\text { de SP }\end{array}$ & $\begin{array}{l}\text { World University } \\
\text { Rankings }\end{array}$ & Region & State & $\begin{array}{l}\text { Number of } \\
\text { Fellowships }\end{array}$ & $\begin{array}{c}\text { Percentage } \\
(\%)\end{array}$ \\
\hline USP & $1^{\text {st }}$ & $1^{\text {st }}$ & $1^{\text {st }}$ & Southeast & SP & 38 & 19.7 \\
\hline UFRJ & $2^{\text {nd }}$ & $3^{\text {rd }}$ & $11^{\text {th }}$ & Southeast & RJ & 15 & 7.9 \\
\hline UNIFESP & $2^{\text {nd }}$ & $16^{\text {th }}$ & $6^{\text {th }}$ & Southeast & SP & 15 & 7.9 \\
\hline UFMG & $3^{\text {rd }}$ & $4^{\text {th }}$ & $3^{\text {th }}$ & Southeast & MG & 13 & 6.8 \\
\hline UFRGS & $4^{\text {th }}$ & $5^{\text {th }}$ & $4^{\text {th }}$ & South & $\mathrm{RS}$ & 10 & 5.2 \\
\hline UNICAMP & $4^{\text {th }}$ & $2^{\text {th }}$ & $2^{\text {th }}$ & Southeast & SP & 10 & 5.2 \\
\hline UFES & $5^{\text {th }}$ & $27^{\text {th }}$ & $20^{\text {th }}$ & Southeast & ES & 9 & 4.7 \\
\hline UNESP & $5^{\text {th }}$ & $6^{\text {th }}$ & $13^{\text {th }}$ & Southeast & SP & 9 & 4.7 \\
\hline UERJ & $6^{\text {th }}$ & $13^{\text {th }}$ & $46^{\text {th }}$ & Southeast & RJ & 5 & 2.6 \\
\hline UFF & $6^{\text {th }}$ & $17^{\text {th }}$ & $41^{\text {th }}$ & Southeast & RJ & 5 & 2.6 \\
\hline UFSM & $6^{\text {th }}$ & $21^{\text {th }}$ & $36^{\text {th }}$ & South & $\mathrm{RS}$ & 5 & 2.6 \\
\hline UFPR & $7^{\text {th }}$ & $8^{\text {th }}$ & $31^{\text {th }}$ & South & PR & 4 & 2.1 \\
\hline UFSC & $7^{\text {th }}$ & $7^{\text {th }}$ & $5^{\text {th }}$ & South & $\mathrm{SC}$ & 4 & 2.1 \\
\hline FURG & $8^{\text {th }}$ & $54^{\text {th }}$ & $4^{\text {th }}$ & South & $\mathrm{RS}$ & 3 & 1.6 \\
\hline UFG & $8^{\text {th }}$ & $20^{\text {th }}$ & $21^{\text {th }}$ & $\begin{array}{l}\text { Central- } \\
\text { West }\end{array}$ & GO & 3 & 1.6 \\
\hline UFOP & $8^{\text {th }}$ & $39^{\text {th }}$ & $28^{\text {th }}$ & Southeast & MG & 3 & 1.6 \\
\hline UFRN & $8^{\text {th }}$ & $22^{\text {th }}$ & $34^{\text {th }}$ & Northeast & $\mathrm{RN}$ & 3 & 1.6 \\
\hline Others & - & - & - & - & - & $29 *$ & 19.5 \\
\hline Total & - & - & - & - & - & 193 & 100 \\
\hline
\end{tabular}

PQ: Productivity researchers. Ranking of universities prepared by Folha de São Paulo (2019). World University Rankings prepared by Times Higher Education data filtered by country (2021). *Ten institutions have 2 researchers each (MACKENZIE - Mackenzie Presbiterian University, PUCRS - Pontifical Catholic University of Rio Grande do Sul, UEM - State University of Maringá, UFC - Federal University of Ceará, UFPA - Federal University of Pará, UFPE - Federal University of Pernambuco, UFRRJ - Federal Rural University of Rio de Janeiro, UNICSUL - Cruzeiro do Sul University, UNIFAL - Federal University of Alfenas and UNIPAMPA - Federal University of Pampa), and another nineteen institutions have one researcher each (CNPEM - National Center for Research in Energy and Materials, FIOCRUZ - Oswaldo Cruz Foundation, UECE - State University of Ceará, UEL - State University of Londrina, UERN - State University of Rio Grande do Norte, UFABC - Federal University of ABC, UFBA - Federal University of Bahia, UFCSPA - Federal University of Health Sciences of Porto Alegre, UFJF - Federal University of Juiz de Fora, UFMA - Federal University of Maranhão, UFPEL - Federal University of Pelotas, UFPI - Federal University of Piauí, UFTM - Federal University of Triângulo Mineiro, ULBRA - Lutheran University of Brazil, UNB - University of Brasilia, UNIMONTES - State University of Montes Claros, UNINOVE - University Ninth of July, UNISUL - University of Southern Santa Catarina and UVV - University of Vila Velha) totaling 29 fellows. USP - University of São Paulo, UFRJ - Federal University of Rio de Janeiro, UNIFESP - Federal University of São Paulo, UFMG - Federal University of Minas Gerais, UFRGS - Federal University of Rio Grande do Sul, UNICAMP - State University of Campinas, UFES - Federal University of Espirito Santo, UNESP - State University of Paulista, UERJ - State University of Rio de Janeiro, UFF - Federal University of Fluminense, UFSM - Federal University of Santa Maria, UFPR - Federal University of Paraná, UFSC - Federal University of Santa Catarina, FURG - Federal University of Rio Grande, UFG - Federal University of Goiás, UFOP - Federal University of Ouro Preto and UFRN - Federal University of Rio Grande do Norte.

Source: Authors own elaboration (2021).

In relation to the PhD time of the PQ researchers in Physiology, the research with the shortest PhD time had 6 years of obtaining the title, while the longest degree had been given 58 years. We found 39 different training areas for researchers in terms of obtaining a doctorate. According to the data obtained in the researchers' Lattes Curriculum, the most prominent area was Physiology (45\%), followed by Biophysics (7\%) and Pharmacology (6\%).

We categorized fellowship holders by doctoral time, so that we obtained $9 \%$ of researchers with a doctoral time between 5 and 10 years, 23\% between 11 and 15 years, 18\% between 16 and 20 years, $21 \%$ between 21 and 25 years, $9 \%$ between 26 and 30 years old, $8 \%$ between 31 and 35 years old, 7\% between 36 and 40 years, $4 \%$ between 41 and 45 years and 
$1 \%$ of the researchers have a $\mathrm{PhD}$ between 46 and 50 years old, as well as for the category 55 to 66 years. We grouped the information related to the doctorate time associated with the category of PQ fellowship to which the researcher fits. These information are shown in Figure 1.

Figure 1: Doctorate time per category of PQ fellowship for researchers in the field Physiology.

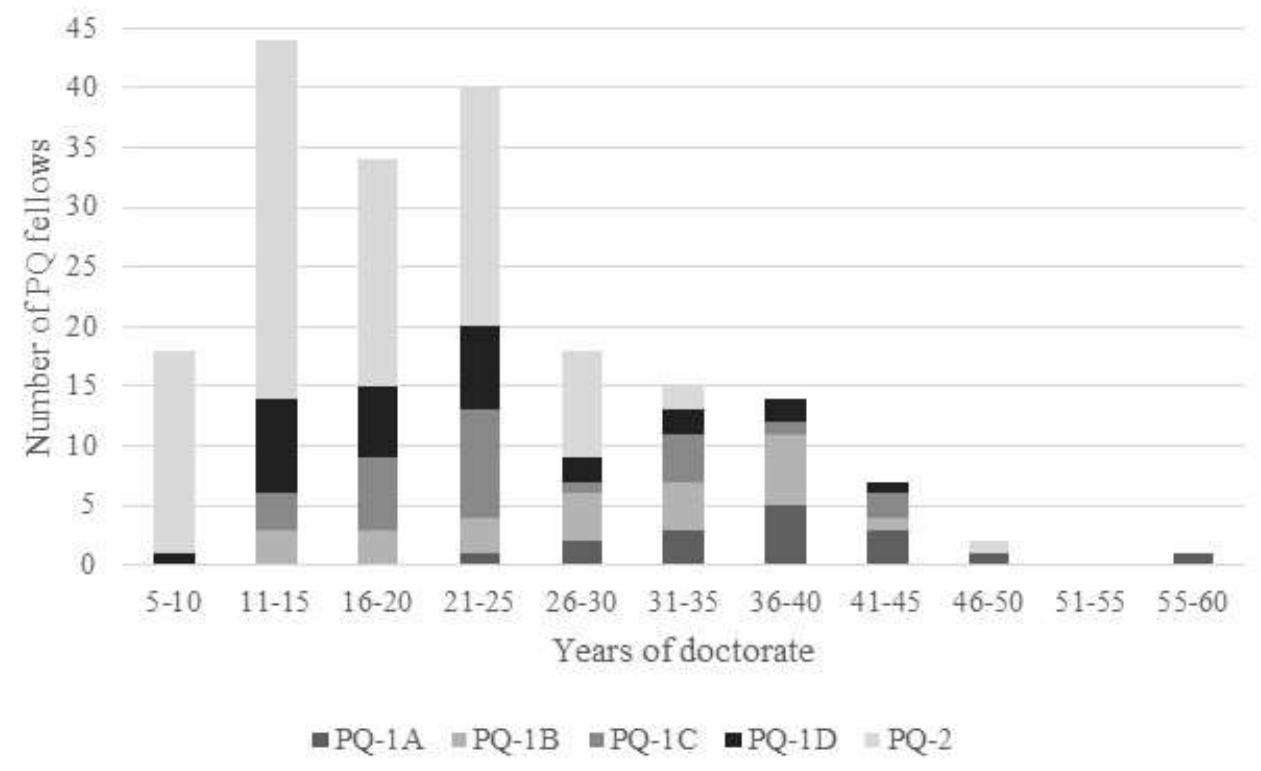

PQ: Productivity researchers. Source: Authors own elaboration (2021).

Regarding the productivity of the Physiology fellows, we seek the total production per researcher reported in the respective Lattes Curriculum and the production in the last 5 years. Thus, we obtained a total of 20.184 published articles, adding up all categories, when analyzing all reported articles. When we analyzed only the articles published in the last five years (2015-2020), we obtained a total of 6.890 published articles, with the average of publication per researcher being 41 articles.

The maximum and minimum amount of publication by categories, referring to the last 5 years, is as it follows: PQ-1A (min:17, max:186), PQ-1B (min: 11, max: 144), PQ-1C (min: 11, max: 66), PQ-1D (min: 8, max: 91) and PQ-2 (min: 1, max: 94). 15.274 articles were indexed in Web of Science databases, with the average number of articles per researcher being 136.6 articles. In the Scopus database, 11.240 were indexed. The average number of articles per researcher on this basis was 179.3 articles. Information regarding the means and standard deviations for each category is shown in Tables 4. 
Table 4: Productivity of PQ fellows in Physiology.

\begin{tabular}{lcccccc}
\hline Category & $\begin{array}{c}\text { Articles } \\
\text { published in } \\
\text { journals* }\end{array}$ & & Web of Science & & & SCOPUS \\
& & Total articles & Citation & Fator H & Total articles & Citation \\
\hline PQ-1A & $68.0 \pm 42.2$ & $290 \pm 169$ & $4918 \pm 2974$ & $36 \pm 14$ & $528 \pm 679$ & $4197 \pm 918$ \\
\hline PQ-1B & $41.6 \pm 26.3$ & $153 \pm 70$ & $1891 \pm 639$ & $24 \pm 4$ & $143.2 \pm 52$ & $2235 \pm 868$ \\
\hline PQ-1C & $34.0 \pm 14.9$ & $91 \pm 29$ & $1710 \pm 947$ & $22 \pm 5$ & $82 \pm 27$ & $1686 \pm 1035$ \\
\hline PQ-1D & $30.0 \pm 15.8$ & $84 \pm 39$ & $1370 \pm 896$ & $20 \pm 5$ & $76 \pm 35$ & $1430 \pm 993$ \\
\hline PQ-2 & $31.4 \pm 20.0$ & $64 \pm 38$ & $992 \pm 821$ & $16 \pm 6$ & $68 \pm 96$ & $882 \pm 787$
\end{tabular}

PQ: Productivity researchers; Mean \pm Standard Deviation (SD). *Data from the Lattes Curriculum, grouped by categories. Source: Authors own elaboration (2021).

Also, in terms of productivity, in addition to publications the parameter relates to the training to human resources are analyzed. Thus, we highlight, in Table 5, the amount of guidance in the categories of Master, Doctorate, Post-doctorate and Scientific Initiation according to information extracted from Lattes of each researcher, grouped by fellowship category.

Table 5: Amount of guidance by category of PQ fellows in Physiology.

\begin{tabular}{ccccccc}
\hline Category & \multicolumn{3}{c}{ Amount of guidance } & \multicolumn{2}{c}{ Total } \\
\hline & Master & Doctorate & Post-doctorate & SC & N & $\%$ \\
PQ-1A & 554 & 613 & 261 & 571 & 1999 & 17 \\
PQ-1B & 578 & 472 & 170 & 456 & 1676 & 14 \\
PQ-1C & 503 & 438 & 147 & 609 & 1697 & 14 \\
PQ-1D & 485 & 384 & 120 & 801 & 1790 & 15 \\
PQ-2 & 1354 & 1021 & 230 & 2090 & 4695 & 40 \\
Total & 3474 & 2928 & 928 & 4527 & 11857 & 100 \\
\hline
\end{tabular}

PQ: Productivity researchers; SC - scientific initiation; N: Absolute frequency. Source: Authors own elaboration (2021).

We also analyzed the weighted value referring to the number of articles in the Lattes Curriculum throughout the career of the fellows and the total number of guidelines for each category. So, we found these values for each category PQ-1A (2.3), PQ-1B (2.1), PQ-1C (1.7), PQ-1D (1.3) and PQ-2 (1.5).

We seek to know the research lines of researchers' productivity in Physiology. According to the information recorded in the Lattes, 33 different lines of research were found, the most prevalent being Cardiovascular Physiology (30\%), Endocrine Physiology (15\%) and Neurosciences (14\%).

We also investigated how many Post-graduation (PG) programs the fellows in Physiology are linked to, through information extracted from Lattes. Thus, we observed that 109 from 193 researchers are linked to only one PG program (56.5\%), $65(33.7 \%)$ are linked to two PG programs, $15(7.7 \%)$ are linked to three and four (2.1\%) researchers are accredited in four PG programs. Other relevant information was that 14 researchers are linked to Multicentric Graduate Program in Physiological Science coordinated by the Brazilian Society of Physiology.

When analyzing the total number of PG programs reported in Lattes, we found a total of 152 PG programs, of which $46(27.6 \%)$ are in the area of Biological Sciences II (CB II) according to CAPES. In relation to the assessment concepts 
attributed to PG programs, 20 received a score of 7, the maximum score attributed by CAPES, other 27 programs received a score of 6, 45 were scored as 5, 47 programs received a score of 4 and 12 programs are recorded with a score of 3 . Those scores were extracted from Sucupira Platform.

\section{Discussion}

Our findings point to indicators referring to the profile, scientific production and postgraduate programs of researchers from CNPq Productivity in the field of Physiology in Brazil. According to data extracted in May 2020, there are 193 researchers with current fellowships, distributed in all regions of the country.

Regarding the profile of the researchers, there was a predominance of males and category 2 (PQ-2) among PQ fellows. Concerning the doctorate, it was observed that fellows belonging to the category PQ-1A had more than 21 years of obtaining the $\mathrm{PhD}$ titles. We emphasize that the researcher with the longest $\mathrm{PhD}$ degree obtained the title 58 years ago, who belongs to PQ-1A category, while the researcher with the shortest time from getting the PhD title obtained it 6 years ago, belonging to PQ-2 category.

Results referring to the geographic distribution of PQs in Physiology point to a concentration of researchers in the Southeast region (72\%), given that it is also reflected in the number of graduate programs in which researchers are linked to, since 90 programs are located in the Southeast region. Although the focus of the present study was in the area of Physiology, we observed that most of the programs mentioned in the researchers' Lattes were not evaluated by Biological Sciences II (CB II) area, which compromises studies of Physiology, Biophysics, Biochemistry, Pharmacology and Morphology. Only 46 of the programs found were evaluated by CB II and, of these, 23 (50\%) were located in the Southeast region.

CB II area is responsible for evaluating 79 PG programs across the country. As previously mentioned, 23 programs found in our study were located in the Southeast region, which comprises $29 \%$ of the PG programs evaluated by CB II in the country (BRASIL, 2021). Such information reinforces the weight that the Southeast region occupies with regard to the study of biological sciences, especially Physiology. A good example is the Physiology course at the University of São Paulo (USP), Ribeirão Preto campus, which dates back to 1970, reflecting, therefore, the time this area had to consolidate itself in the region and only then start the expansion process to other regions (BRASIL, 2021).

We also highlight that from the 23 programs located in the Southeast, 12 of them are located in São Paulo, which reflects the strong system of state public universities, in addition to the role played by the São Paulo Research Foundation (FAPESP). Such information has a direct impact on the quantity and impact of scientific intellectual production in the state of São Paulo, reaching averages higher than national ones (UNESCO, 2015).

As previously mentioned, there is a male predominance in relation to the distribution of PQ grants. Furthermore, we observed that the higher the category of fellowship, the more evident this disparity becomes. A similar finding was reported by Guedes (2014) when carrying out an analysis of the distribution of PQ grants by sex in all areas, it was evident that although there is a predominance of woman in the hierarchical levels that precede the Productivity category, namely scientific initiation, master's, doctorate, postdoctoral, regarding the amount of all PQ fellowship researchers, only $32 \%$ of them are female (Guedes, 2014).

The Brazilian Society of Physiology (SBFis), in 2018, promoted a discussion on the participation of women in science in its annual congress, where updated data on the distribution of fellowships by sex in the country were presented, however there was no increase in the participation of women regarding the granting of PQ fellowships considering the short term for implementing changes. On this occasion, it was reported that male presence in the PQ category represented $64 \%$ of the total (Mello-Carpes et al., 2019). 
Still, on this occasion, the creation of the Women in Physiology Commission was suggested, in order to support the increasingly effective participation of woman in physiology, especially with regard to the creation and organization of events whose theme addressed is the participation and maintenance of women in the field of physiology; dissemination of programs, notices and awards related to women in science; stimulate discussions on gender equality in science. This commission took effect in 2019 (Mello-Carpes et al., 2019).

In this same event, issues that could be considered as impeding the growth or permanence of women at high levels of productivity and possible solutions to face such barriers were highlighted. Among the challenges pointed out, the need for greater attention on the part of funding agencies and notices, since problems with notices and their approval were highlighted when the review process was not carried out blindly.

Be noteworthy that when the process takes place in this way, the projects elaborated and developed by woman are more likely to be approved (Mello-Carpes et al., 2019). This is because the double-blind evaluation process does not take into account the identity of the author of the project, nor the name of the reviewer, also excluding possible institutional or regional biases. This time, only the product presented would be evaluated, namely, the submitted project, and not the qualification or possible merits of the researcher.

With regard to the quantity and distribution of fellowships by categories, historically the category PQ-2 is responsible for the largest amount of fellowships (Guedes, 2014), a fact also observed in the present study. Still comparing our results with the information presented by Guedes (2014), we note that the standards remain, since higher hierarchical levels are granted to researchers with a longer academic career (Guedes, 2014). However, it is not possible to attribute that the longer the career, the researcher will necessarily raise the level, since the number of available fellowships is still quite reduced to the detriment of qualified demand.

Regarding this issue, we highlight the cuts in fellowships from the main research funding agencies in Brazil (CNPq and CAPES), affecting the research field and, therefore, the PQ researchers. Although, as previously mentioned, a large portion of PQ fellowship holders are concentrated in the southeastern region, which has one of the largest state development agencies (FAPESP), this is not routine in other states/regions. Reflecting directly on the researchers' productivity and, thus, on the possibility of pleading and reaching the position of Productivity in their scientific career.

Considering the institutions to which the researchers are linked, we show that 10 institutions with the largest number of fellows are among the 20 best institutions in the country, based on the National Folha de São Paulo ranking ("Ranking de universidades - RUF 2019 | Folha,” 2019). When based on World University Rankings, they are among the top 50 institutions in the country. Analyzing these data in more detail, we realize that the four best institutions of higher education according to World University Rankings ("World University Rankings," 2020) are in the list of institutions to which PQ fellowships in Physiology are linked, namely, USP, UNICAMP, UFMG and UFRGS, public institutions with a long period of operation and very consolidated at the national level, as well as at the international level.

Kamdem et al. (2019) analyzed the productivity of PQ fellowships in different areas of Biomedical Sciences, with an average of 103.53 publications indexed in the Scopus database by PQ-1 fellows in Physiology. Currently, we found an average of 179.3 articles per researcher, we reinforce that our data were extracted form Lattes Platform of each researcher, there is a field referring to the number of citations in some databases, such as Scopus and this does not count the period in which these articles have been indexed. We emphasize that this information refers to all categories (PQ-1 and PQ-2).

According to our data, the area of Physiology has shown an increase in the number of publications, as well as fellowship holders, since it was shown by Kamdem et al. (2019) a total of 88 fellows and currently one observed 193 fellows. It is worth mentioning that they analyzed only the levels belonging to PQ-1 category and, in our study, we analyzed all fellowships holders (PQ-1A, PQ-1B, PQ-1C, PQ-1D and PQ-2) (Jean Paul Kamdem et al., 2019). 
Regarding the training of human resources, the PQ-2 category deserves mention, which represents $40 \%$ of the total training. Analyzing the levels individually, as previously mentioned, we noticed that the category PQ-2 stands out at all levels, except post-doctorate, in which the category PQ-1A stands out. A possible justification would be the longer career of researchers belonging to this category and with that a longer period for training human resources, however, such information does not seem to be entirely true, since the levels PQ-1B, 1C and 1D do not follow this standard, with even fewer graduates compared to PQ-2.

However, when we analyze the weighted value referring to the number of publications throughout the researchers' careers and the total number of orientations, we observe that the values found correspond to the expected order $(2.3-1 \mathrm{~A} ; 21-$ $1 \mathrm{~B} ; 1.7-1 \mathrm{C} ; 1.3$ - 1D and 1.5 - 2). In other words, although PQ-2 category presents $40 \%$ of the total training of human resources, when we analyze the weighted value, we realize that the largest production is, in fact, attributed to PQ-1A fellowship holders.

The present study pointed out a disparity regarding the heterogeneous distribution of PQ fellows in the Brazilian territory, with a predominant concentration in the Southeast region. Thus, we hope to contribute, based on the present data, with initiatives aiming at greater investment and expansion of the area to other regions of the country, thus allowing research to advance to other Higher Education Institutions, other than those already renowned. We also intend that our data will serve to reinforce the existing support and incentive movements for women in science, as well as research in its general scope, with greater support from both public and private development institutions.

We emphasize the reliability of data, since all the information was extracted from databases used throughout the national territory, in an open and transparent manner. Thus, even though we are aware that Lattes Platform is powered by the users themselves, we assume that all the information reported was in fact true. Data from the present study were extracted in May 2020, so we assume that over the period for analysis and preparation of the article, information may have changed, namely, changes in the total number of fellows, with an increase in the total number or changes between the categories.

We also highlight the need for studies with this proposal in order to encourage researchers in their respective areas of expertise, in addition to alerting the scientific community about the need for more investments in research. Therefore, it is recommended to frequently update the number of active researchers, their geographic distribution, scientific production, in addition to the number of resources granted by research funding agencies.

\section{Conclusion}

In the view of the results presented in our study, we conclude that although researchers from all over Brazil may apply for a Productivity Fellowship in the area of Physiology, these still remain implemented primarily for male researchers and concentrated in the Southeast region, thus revealing the disparity present in the distribution of information especially at higher hierarchical levels. The most outstanding doctoral areas obtained among PQ fellows were Physiology, followed by Biophysics and Pharmacology. Regarding the researchers' productivity research interest areas, the most frequent were Cardiovascular Physiology, Endocrine Physiology and Neurosciences. Based on our data, we conclude that the most researchers are linked to only one graduate program and only $46(27.6 \%)$ of them are allocated to the area of Biological Science II.

\section{References}

Barata, R. B., \& Goldbaum, M. (2003). Perfil dos pesquisadores com bolsa de produtividade em pesquisa do CNPq da área de saúde coletiva. Cadernos de Saúde Pública, 19(6), 1863-1876. https://doi.org/10.1590/S0102-311X2003000600031

Brasil. (2019). MCTIC, Ministério da Ciência, Tecnologia, Inovações e Comunicações. Produção Científica website: https://www.mctic.gov.br/mctic/ opencms/indi cadores/detalhe/Producao_Cientifica/Producao_Cientifica_5.5.html 
Brasil. (2021). Plataforma Sucupira. https://sucupira.capes.gov.br/sucupira/public/consultas/coleta/programa/quant itativos/quantitativoPrograma.xhtml?are aAvaliacao $=8 \&$ areaConhecimento $=20700008 \&$ cdRegiao $=0 \&$ ies $=338689$

Cross, D., Thomson, S., \& Sibclair, A. (2018). Research in Brazil: A report for CAPES by Clarivate Analytics. Clarivate Analytics.

Guedes, M. de C. (2014). Bolsas e bolsistas de produtividade do CNPq: Uma análise de gênero. Anais Eletrônicos Do 14 Seminário Nacional de História Da Ciência e Da Tecnologia. Presented at the Belo Horizonte, Campus Pampulha da Universidade Federal de Minas Gerais. Belo Horizonte, Campus Pampulha da Universidade Federal de Minas Gerais.

Kamdem, Jean P., Abolaji, A. O., Roos, D. H., Calabró, L., Barbosa, N. V., Souza, D. O., \& Rocha, J. B. T. (2016). Scientific Performance of Brazilian Researchers in Pharmacology with grants from CNPq: A comparative study within the Brazilian categories. Anais Da Academia Brasileira De Ciencias, $88(3$ Suppl), 1735-1742. https://doi.org/10.1590/0001-3765201620150534

Kamdem, Jean Paul, Roos, D. H., Sanmi, A. A., Calabró, L., Abolaji, A. O., de Oliveira, C. S., \& Rocha, J. B. T. (2019). Productivity of CNPq Researchers from Different Fields in Biomedical Sciences: The Need for Objective Bibliometric Parameters-A Report from Brazil. Science and Engineering Ethics, 25(4), 1037-1055. https://doi.org/10.1007/s11948-018-0025-5

Leite, A. C. F., \& Neto, I. R. (2017). Perfil dos Bolsistas de Produtividade em Pesquisa do CNPq em Educação. Revista Brasileira de Ensino Superior, 3(4), 97-112. https://doi.org/10.18256/2447-3944.2017.v3i4.2350

Martelli-Junior, H., Martelli, D. R. B., Quirino, I. G., Oliveira, M. C. L. A., Lima, L. S., \& Oliveira, E. A. de. (2010). Pesquisadores do CNPq na área de medicina: Comparação das áreas de atuação. Revista da Associação Médica Brasileira, 56(4), 478-483. https://doi.org/10.1590/S0104-42302010000400024

Mello-Carpes, P. B., Abreu, A. R. de P., Staniscuaski, F., Souza, M. A., Campagnole-Santos, M. J., \& Irigoyen, M. C. (2019). Actions developed by the Brazilian Physiological Society to promote women's participation in science. Advances in Physiology Education, 43(2), 199-206. https://doi.org/10.1152/advan.00216.2018

Oliveira, E. A. de, Ribeiro, A. L. P., Quirino, I. G., Oliveira, M. C. L., Martelli, D. R., Lima, L. S., \& Martelli-Junior, H. (2011). Pesquisadores do Conselho Nacional de Desenvolvimento Científico e Tecnológico na área de Cardiologia. Arquivos Brasileiros de Cardiologia, 97(3), 186-193. https://doi.org/10.1590/S0066-782X2011005000086

Pereira, A. S., Shitsuka, D. M., Parreira, F. J., \& Shitsuka, R. (2018). Metodologia da pesquisa cientifica. [E-book grátis]. UFSM. Retrieved from https://repositorio.ufsm.br/bitstream/handle/1/15824/Lic_Computacao_Metodologia-Pesquisa-Cientifica.pdf?sequence=1

Ranking de universidades_-RUF 2019 | Folha. (2019). Ranking Universitário Folha website: //ruf.folha.uol.com.br/2019/ranking-de-universidades/principal/

Sacco, A. M., Valiente, L., Vilanova, F., Wendt, G. W., DeSousa, D. A., Koller, S. H., \& Koller, S. H. (2016). Perfil dos Bolsistas de Produtividade em Pesquisa do CNPq atuantes em Psicologia no Triênio 2012-2014. Psicologia: Ciência e Profissão, 36(2), 292-303. https://doi.org/10.1590/19823703002702015

Santos, N. C. F., Cândido, L. F. de O., \& Kuppens, C. L. (2010). Produtividade em pesquisa do CNPq: Análise do perfil dos pesquisadores da Química. Química Nova, 33(2), 489-495. https://doi.org/10.1590/S0100-40422010000200044

Scarpelli, A. C., Sardenberg, F., Goursand, D., Paiva, S. M., \& Pordeus, I. A. (2008). Academic trajectories of dental researchers receiving CNPq's productivity grants. Brazilian Dental Journal, 19(3), 252-256. https://doi.org/10.1590/S0103-64402008000300014

Sturmer, G., Viero, C. C. M., Silveira, M. N., Lukrafka, J. L., \& Plentz, R. D. M. (2013). Profile and scientific output analysis of physical therapy researchers with research productivity fellowship from the Brazilian National Council for Scientific and Technological Development. Brazilian Journal of Physical Therapy, 17(1), 41-48. https://doi.org/10.1590/S1413-35552012005000068

UNESCO. (2015). Relatório de Ciência da UNESCO - rumo a 2030: Visão Geral e Cenário Brasileiro. Retrieved January 18, 2021, from https://unesdoc.unesco.org/ark:/48223/pf0000235407_por/PDF/235407por.pdf.multi

Wainer, J., \& Vieira, P. (2013). Avaliação de bolsas de produtividade em pesquisa do CNPq e medidas bibliométricas: Correlações para todas as grandes áreas. Perspectivas em Ciência da Informação, 18(2), 60-78. https://doi.org/10.1590/S1413-99362013000200005

World University Rankings. (2020). Times Higher Education (THE) website: https://www.timeshighereducation.com/world-university-rankings/2021/worldranking 